\title{
Clinical subtype of HAM/TSP based on clinical course and laboratory findings
}

\author{
Yoshihisa Yamano ${ }^{1 *}$, Tomoo Sato', Natsumi Araya ${ }^{1}$, Naoko Yagishita', Yukiko Shimizu', Hitoshi Ando', \\ Atae Utsunomiya ${ }^{2}$, Shuji Izumo ${ }^{3}$, Steven Jacobson ${ }^{4}$, Noboru Suzuki ${ }^{1}$ \\ From 15th International Conference on Human Retroviruses: HTLV and Related Viruses \\ Leuven and Gembloux, Belgium. 5-8 June 2011
}

The clinical course and disease activity of patients with HTLV-1 associated myelopathy / tropical spastic paraparesis (HAM/TSP) are different among patients. Therefore, the treatment plan should be designed based on these backgrounds of patients. However, there is little information about the natural history of HAM/TSP and biomarkers of disease activity that is associated with prognosis.

As the candidate for biomarkers to evaluate the disease activity in HAM/TSP, HTLV-1 proviral load in PBMC, several cytokines and chemokines in serum or cerebrospinal fluid (CSF) are known to be increased in HAM/TSP patients. However, little is known which parameter of these candidates is most associated with disease severity.

Therefore, we investigated the clinical course of 30 HAM/TSP patients without any history of treatment. Furthermore, we measured quantitatively the concentration of a series of cytokines and chemokines in serum and CSF, and HTLV-1 proviral DNA load in PBMC. Then, the level of these markers was evaluated for the correlation with disease severity.

In HAM/TSP patients, the level of CXCL10/IP-10 and neopterin in CSF was strongly correlated with disease severity. Interestingly, the level of soluble IL-2 receptor and CXCL10/IP-10 in serum was also correlated with disease severity with statistical significance. Furthermore, based on the clinical course and laboratory findings, HAM/TSP was classified into 4 different clinical subtypes as follows; (1) Rapidly progressive (active), (2-A) Chronic progressive (active), (2-B) Chronic progressive (inactive), (3) Chronic mild (inactive). This classification

\footnotetext{
* Correspondence: yyamano@marianna-u.ac.jp

${ }^{1}$ Institute of Medical Science, St. Marianna University School of Medicine, Kawasaki, Japan

Full list of author information is available at the end of the article
}

might be useful to determine the therapeutic strategy for patients with HAM/TSP.

\begin{abstract}
Author details
${ }^{1}$ Institute of Medical Science, St. Marianna University School of Medicine, Kawasaki, Japan. ${ }^{2}$ Department of Hematology, Imamura Bun-in Hospital, Kagoshima, Japan. ${ }^{3}$ Molecular Pathology, Center for Chronic Viral Diseases, Graduate School of Medical and Dental Sciences, Kagoshima University, Kagoshima, Japan. ${ }^{4}$ Viral Immunology Section, Neuroimmunology Branch, National Institute of Health, Bethesda, MD, USA.
\end{abstract}

Published: 6 June 2011

doi:10.1186/1742-4690-8-S1-A42

Cite this article as: Yamano et al:: Clinical subtype of HAM/TSP based on clinical course and laboratory findings. Retrovirology 2011 8(Suppl 1): A42.

Submit your next manuscript to BioMed Central and take full advantage of:

- Convenient online submission

- Thorough peer review

- No space constraints or color figure charges

- Immediate publication on acceptance

- Inclusion in PubMed, CAS, Scopus and Google Scholar

- Research which is freely available for redistribution

Submit your manuscript at www.biomedcentral.com/submit
() Biomed Central

\section{() Biomed Central}

(c) 2011 Yamano et al; licensee BioMed Central Ltd. This is an open access article distributed under the terms of the Creative Commons Attribution License (http://creativecommons.org/licenses/by/2.0), which permits unrestricted use, distribution, and reproduction in any medium, provided the original work is properly cited. 